DOI: https://doi.org/10.32839/2304-5809/2020-3-79-42

UDC 528.946

Sohor Andrii, Sohor Markiian

Lviv Polytechnic National University

\title{
WEB-MAPPING OF ENVIRONMENTAL POLLUTION OF SURFACE WATERS
}

Summary. At present, the status of water bodies in the present world is at an unsatisfactory level. The main problems in this area are the progressive nature of the negative impact on the environmental and human health. The main purpose of this work is web-mapping of surface water pollution. To create an interactive webmap, we used the rather convenient and popular ArcGIS Online environment, which makes it easy to upload files and add content from an electronic cloud. In order to use the web application and build a web-map in it, you need to create an account that will be publicly available for viewing and using online. Thus, exploring the problem of web-mapping, we collected and systematized geospatial data on the ecological status of surface waters and identified the necessary software to develop an interactive map. An algorithm for uploading geospatial data to the created web-resource was developed and an application template was selected in ArcGIS Online.

Keywords: geospatial data, State Service of Geodesy, Cartography and Cadastre, ecological mapping, surface water pollution, interactive map, ArcGIS Online environment, Microsoft Office Excel environment.

Corop A.P., Corop M.A.

Національний університет «Львівська політехніка»

\section{WЕВ-КАРТОГРАФУВАННЯ ЕКОЛОГІЧНОГО ЗАБРУДНЕННЯ ПОВЕРХНЕВИХ ВОД}

Анотація. Забезпечення збалансованого, екологічно безпечного розвитку окремих територій держави можливе лише за умов розуміння, як функціонують природні та антропогенні комплекси, що перебувають у їх межах. Такий цілісний підхід до вивчення природних і техногенних об'єктів та використання отриманої на його основі екологічної інформації в процесі прийняття управлінських рішень визначають важливість і необхідність застосування сучасних географрічних методологій. На даний час стан водних об’ектів у теперішньому світі знаходиться на незадовільному рівні. Основними проблемами у цій сфері $е$ прогресуючий характер негативного впливу на екологічний стан довкілля та здоров'я людей. Головною метою ціеї роботи $е$ web-картографрвання забруднення поверхневих вод. Для створення інтерактивної веб-карти ми скористалися досить зручним та популярним середовищем "ArcGIS Online», яке дозволяе легко передавати фрайли та додавати вміст із електронної хмари. Підтримуеться багато типів файлів, включаючи електронні таблиці, KML, GeoJSON та звичайні геопросторові фрайли. ArcGIS Online включає інструменти, які допомагають підготувати їх до візуалізації та аналізу. Інтерактивні web-карти підтримують в собі візуалізацію, редагування та аналіз інформації, їх можна переглядати за допомогою мобільних та комп'ютерних пристроїв. Для того щоб користуватись web-програмою та будувати в ній web-карту, потрібно створити обліковий запис, який буде загальнодоступним для перегляду та користування в режимі онлайн. Цей запис е безкоштовним і дає змогу користуватись персональним інтернет-сховищем для зберігання даних і дозволяе створювати, обробляти та зберігати фрайли та карти. Таким чином, досліджуючи проблему web-картографування, нами було зібрано та систематизовано геопросторові дані щодо екологічного стану поверхневих вод та визначено необхідне програмне забезпечення для розробки інтерактивної карти. Розроблено алгоритм завантаження геопросторових даних у створюваний web-ресурс та підібрано шаблон аплікацій в середовищі «ArcGIS Online». Також в середовищі «ArcGIS Online» розроблено дві інтерактивні web-карти на прикладі забруднення поверхневих вод Львівської області.

Ключові слова: геопросторові дані, Держгеокадастр, екологічне картографування, забруднення поверхневих вод, інтерактивна карта, середовище «ArcGIS Online», середовище «Microsoft Office Excel».

Tormulation of the problem. Insufficiently treated sewage of industrial and municipal enterprises are the main sources of pollution and clogging of reservoirs. Pollutants entering natural reservoirs lead to qualitative changes in water, which are mainly manifested in changes in the physical properties of water (in particular, the appearance of unpleasant odors, flavors, etc.), in the change in the chemical composition of water (in particular, the appearance in it of harmful substances), in the presence of floating substances on the surface of the water and their deposition at the bottom of reservoirs.

Also a serious problem is household wastewater. Household sewage leads to biological contamination of water, which can cause infectious diseases in humans (cholera, typhoid, hepatitis). It is established that nitrates and nitrites cause in the person metagemoglobinemia (oxygen starvation caused by the transition of hemoglobin to metagemoglobin, a substance that is not capable of carrying oxygen), gastric cancer, adversely affect the nervous and cardiovascular system, the development. If the contaminated water is mixed with tap water, it can cause irreparable damage to the human body: damage the kidneys, adversely affect the heart and other organs of the human body. As a result of the ingress of phosphorus compounds into the surface of the reservoir, the phenomenon of eutrophication occurs, which leads to the flowering of water, rapid development of plankton and other microorganisms. As a result, fish, crustaceans, etc. die because aquatic plants, which are increased by fertilizer-phosphates, use all oxygen in water, poison water with the products of their vital activity.

Analysis of recent research and publications. The analysis of modern scientific publications has shown that the problem of ecological 
pollution of surface waters requires considerable attention and detailed study, since the negative change in nature affects the environment and the conditions of existence of all mankind. The use of GIS capabilities and web-technologies can be identified as one of the most established trends in the development of environmental pollution mapping. Unfortunately, in Ukraine, this trend is showing quite slowly.

In foreign experience, the existing issue is resolved by raising the environmental awareness of the population, effective legislation, creating GIS, databases and web-maps. Web-mapping is actively developing in the world, including in the field of environmental pollution mapping. It allows to eliminate existing shortcomings, to provide access to cartographic materials of a wide range of stakeholders, to combine approaches of classical cartography (placement of paper maps on the Internet) with modern methods of geoinformatics (gradual tendency to develop GIS-projects, web-atlases and web-maps).

In Ukraine theme creation interactive map landfills and solid household waste studied scientists N.P. Yarema, O.D. Kubrak and O.V. Serant $[2 ; 3]$. The problems of web-mapping of environmental air pollution have been studied by scientists A.M. Brydun, N.P. Yarema, A.R. Sohor [1].

Highlighting previously unresolved parts of a common problem. Ensuring balanced, ecologically safe development of individual territories of the state is possible only under the understanding of the functioning of natural and anthropogenic complexes within them. Such a holistic approach to the study of natural and man-made objects and the use of environmental information obtained on its basis in the decision-making process determine the importance and necessity of applying modern geographical methodologies.

At present, the status of water bodies in the present world is at an unsatisfactory level. The main problems in this area are the progressive nature of the negative impact on the environmental and human health.

The purpose of the article. The main purpose of this work is web-mapping of surface water pollution.

To achieve this goal, the following tasks have been set and solved:

- Gathering and organizing geospatial data needed to develop an interactive map and select software.

- Development of an algorithm for uploading geospatial data to the created web-resource.

- Selection of statistical geospatial information and application template in ArcGIS Online.

Presenting main material. In this work, we will create a web-map using the ArcGIS Online software environment.

ArcGIS Online is a platform that is the world leader in geo-information systems (GIS) platforms and is used worldwide for the application of geographical knowledge in the areas of public administration, business, science, education and media. ArcGIS allows you to publish geographic information for access and use by any user. Therefore, it is an environment for creating and sharing maps, displaying applications and data, which allows you to use, create and configure access to maps, scenes, layers, applications and data [1].

ArcGIS Online makes it easy to upload files and add content from an electronic cloud. Many file types are supported, including spreadsheets, $K M L$, GeoJSON, and regular geospatial files. If you need to refine your data, ArcGIS Online includes tools to help you prepare for visualization and analysis. Interactive web-maps support the visualization, editing and analysis of information, and can be viewed on mobile and computer devices.

One of the types of maps that can be used in ArcMap is a web-map that can be created in a web-browser using the ArcGIS.com map viewer and used by any ArcGIS client - ArcGIS for Desktop, ArcGIS mobile and web-applications and etc. Access to all ArcGIS mapping services is provided by creating web-maps. It is also possible to use ArcGIS for Desktop to publish the map as a service [2].

In order to use the web-application and build a webmap in it, you need to create an account that will be publicly available for viewing and using online. This recording is free of charge and enables the use of personal online storage for data storage and allows the creation, processing and storage of files and maps [3].

We create the account using the menu of the software environment, which includes 7 sections (Figure 1)

Each of these sections has its own functions, namely:

- Home - the home page that a user navigates to after logging in.

- Gallery - a configured application template that can be used to access a collection of maps, applications, and other content cataloged on the ArcGIS Online network or on the ArcGIS portal.

- Map - a template for downloading, displaying and editing maps.

- Scene - allows you to visualize data and analyze geographic information in an intuitive and interactive $3 D$ environment that has the ability to choose between a global or local scene to better display geospatial data.

- Groups - a collection of maps and applications that typically relate to a particular area of interest.

- Content - a section that includes a list of features: maps, layers, and applications we store.

- Organization - this section identifies the organization that the user of the software environment is on.

ArcGIS enables you to synthesize data from multiple sources into one linked geographic view. These data sources include information from geographic databases, tabular data from database management systems (DBMS) and other systems, files, spreadsheets, photos and videos with geographical labels, $K M L, C A D$-data, real-time sensor data, aerospace and satellite imagery, etc. Virtually any entry with a geographical reference, such as street, city, land ID, GPS-coordinates, etc., can be accessed on the map and can be accessed [3].

Against this background, we will use the rather convenient and popular ArcGIS Online environment to create an interactive web-map. In order to get started in your chosen environment, you need to collect and structure data in Microsoft Office Excel. In our case, three Excel-spreadsheets were developed, namely: 


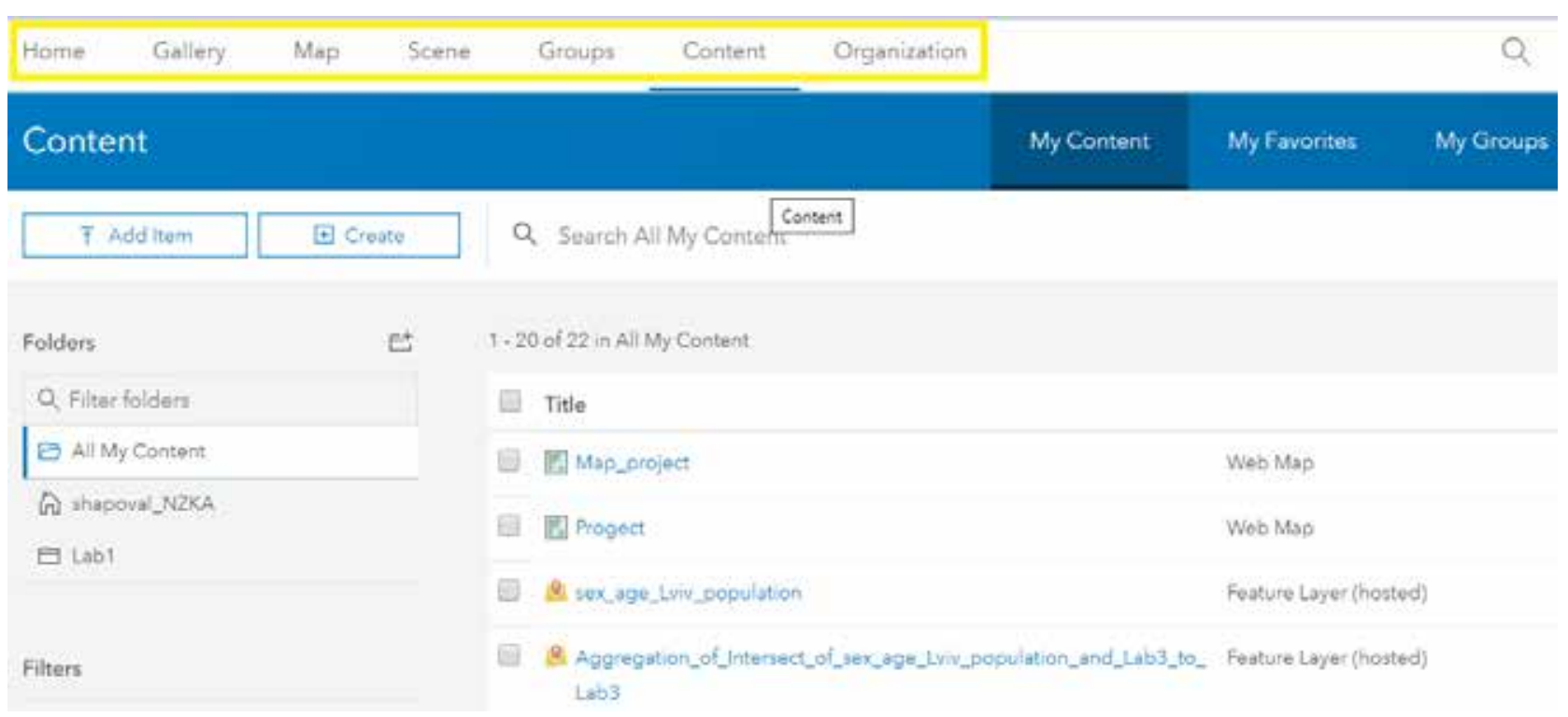

Figure 1. ArcGIS Online Environment Menu

Source: developed by the authors

- With information on recorded excesses by indicators at enterprises surveyed by the State Inspectorate for Inspection in the Lviv region during 2014-2018.

- With information on wastewater discharges after treatment facilities.

- With information on observations of surface water quality on the border rivers.

Many web-maps contain interactive features, such as a base map gallery, which allows you to switch between maps, such as snapshots and streets, as well as measurement tools, pop-ups that display attributes of selected objects, and buttons to display data from over time. Maps are created using layers of data from services and files to convey a specific message or provide the necessary capabilities for the map. Developed maps can be opened in regular web browsers and mobile devices. These maps can be shared using links and inserts on websites $[1 ; 2]$.

In order not to overload the map, it was decided to develop two different interactive maps, each of which would display specific information. To begin with, let's determine the location of surface water pollutant businesses and water sampling points. Google Maps was used to identify each business location to resolve this issue. As well as the location of the sampling points on the rivers. This information is then to be downloaded into ArcGIS Desktop, for this we export the item layer to $K M L / K M Z$ and select the layer to

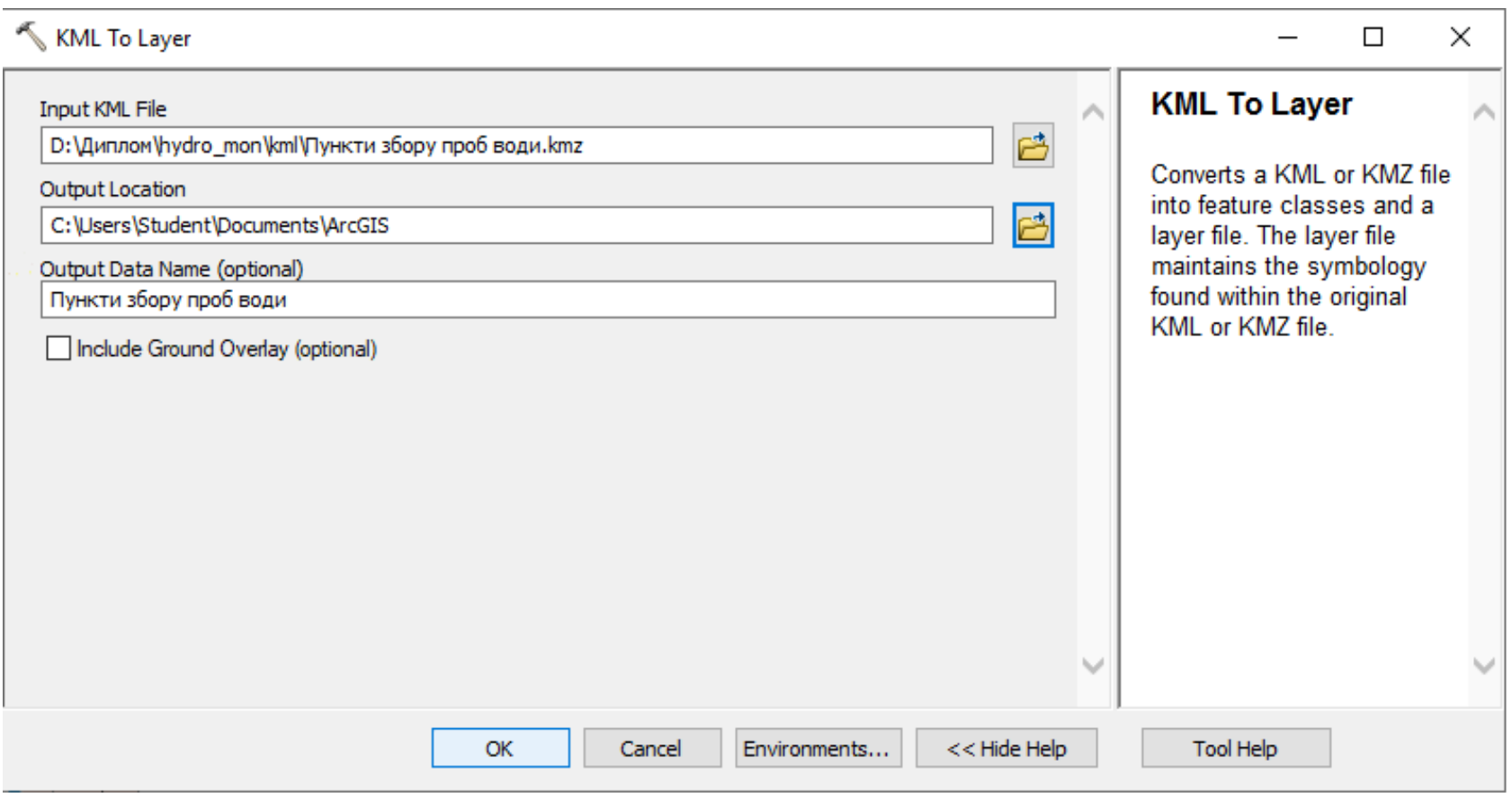

Figure 2. KML To Layer window

Source: developed by the authors 
load. After these actions, we open ArcGIS Desktop, to which a layer with areas of Lviv region has been previously added, open ArcToolbox/Conversion Tools/ From KML/KML to Layer and upload the file to the KML To Layer window (Figure 2).

We then export this downloaded file using ArcToolbox function to Shapefile, to open the above function and find the desired $K M L$-file, and also using Environments enable the values "M Values" and "Z Values".
This information includes $M$-values and $Z$-values commonly used to store route and altitude information.

After loading the data into ArcGIS Desktop, it is necessary to select all rivers for which water samples were taken, for this purpose the function Select By Attributes is used, we select the desired river and add. As a result of all the above actions, we get a web-map in the ArcGis software environment. After the map is loaded in the ArcGIS Desktop en-

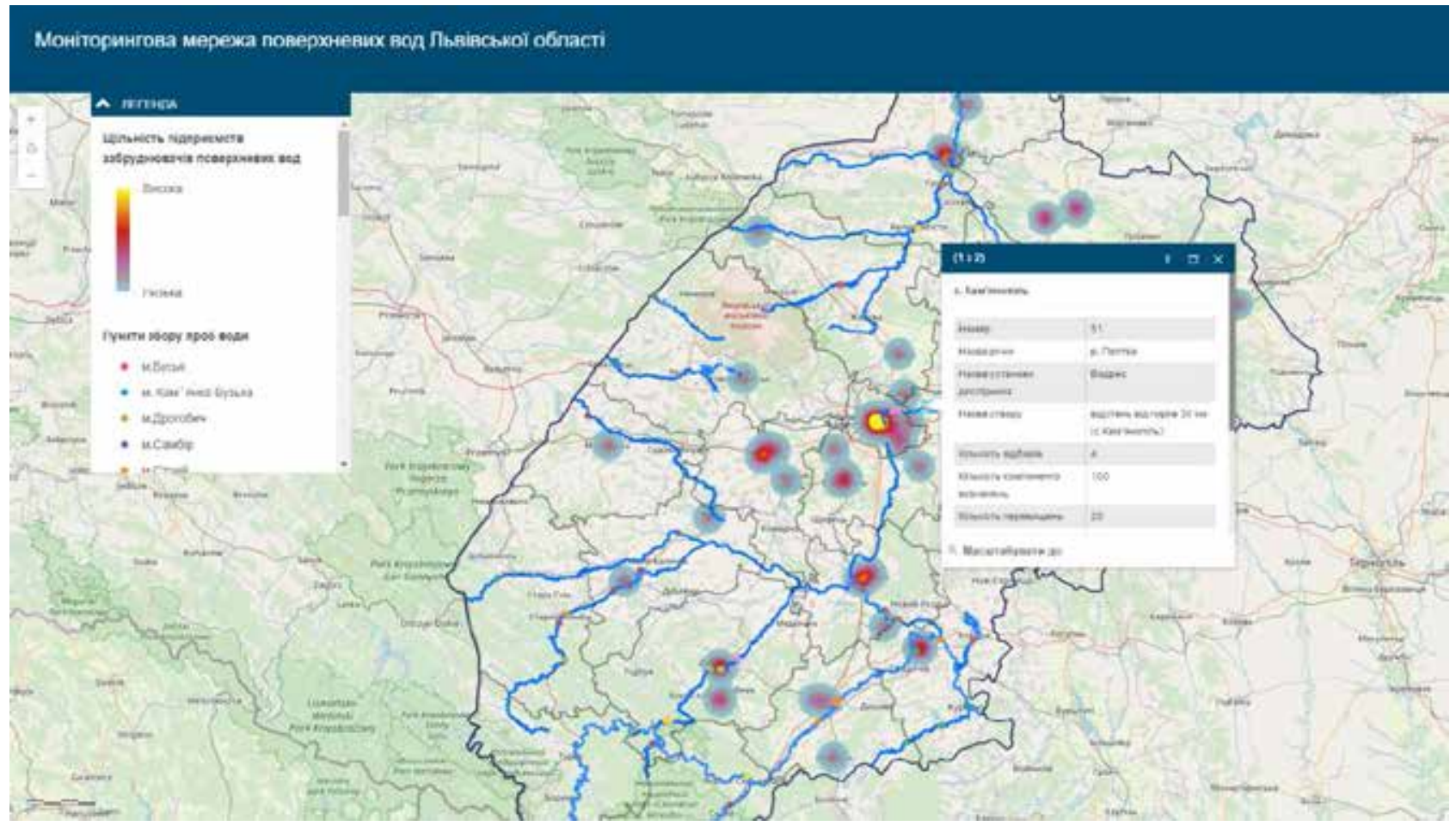

Figure 3. Map of the surface water monitoring network of Lviv region

Source: developed by the authors

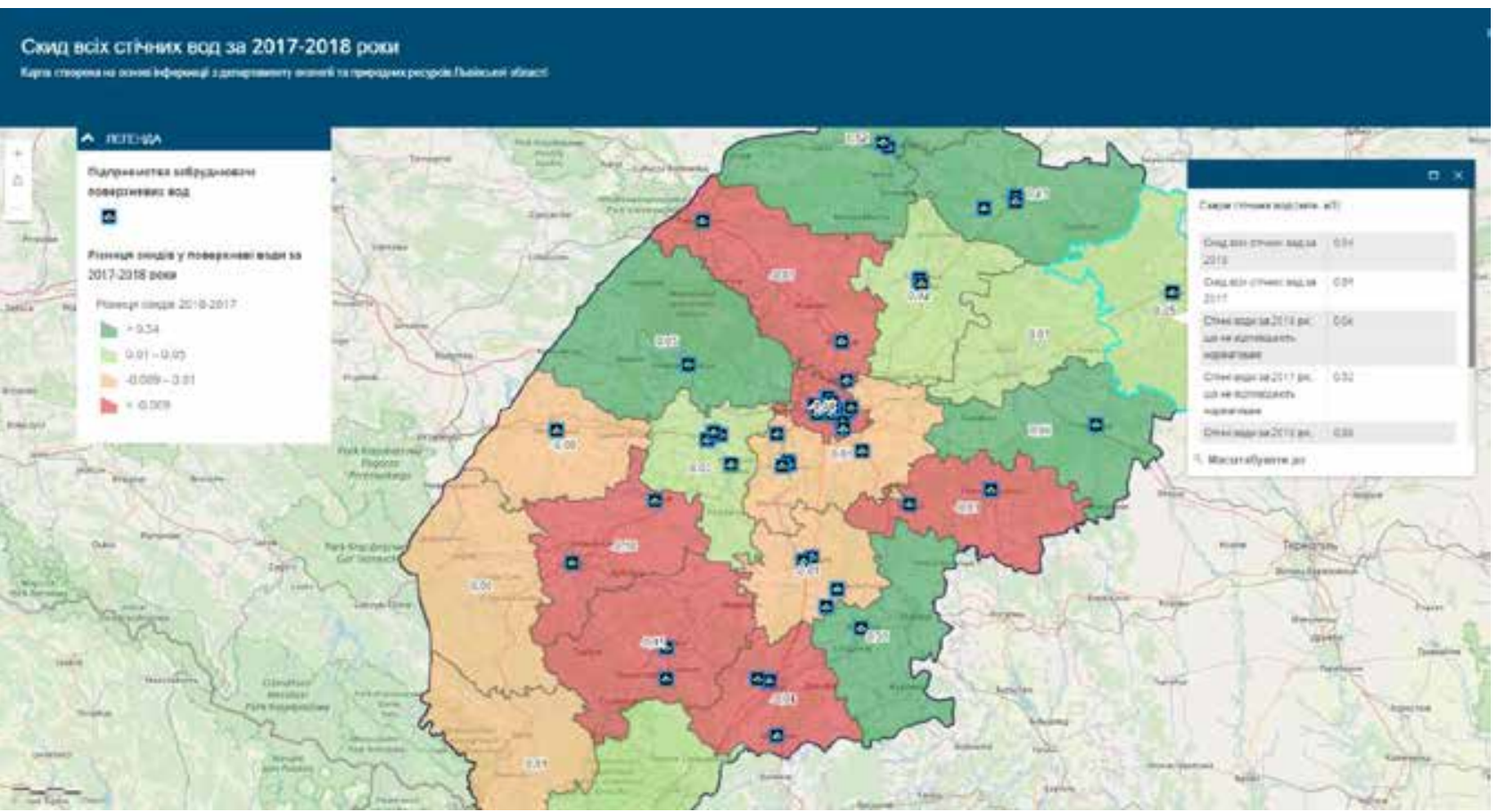

Figure 4. Wastewater discharge map for 2017-2018

Source: developed by the authors 
vironment, all this data must be downloaded into ArcGIS Online, for this purpose all Shapefile data will be exported to the selected folder and archived. After styling, symbolizing and processing all layers, the map can be moved to the public using the Share function. This feature allows you to either insert an existing site or develop your own application. In this case, we have developed our own application.

As a result of these actions, we created two maps with different themes, namely:

- Surface water monitoring network in Lviv region (Figure 3).

- Wastewater discharge for 2017-2018 (Figure 4).

Having received four web-applications, there are several methods for distributing them:
- Share it via social networks.

- Introduce the map to a thematic web-site.

- Share link with friends and acquaintances.

Conclusions and suggestions. Thus, exploring the problem of web-mapping of surface water pollution, we can summarize the following:

1. We have collected and systematized geospatial data on the ecological status of surface waters and identified the necessary software to develop an interactive web-map.

2. An algorithm for uploading geospatial data to the created web-resource was developed and an application template was selected in ArcGIS Online.

3. Two interactive web-maps have been developed in ArcGIS Online.

\section{References:}

1. Sohor, A.R., Yarema, N.P., Brydun, A.M., \& Lekh, I.P. (2019). Stvorennia interaktyvnoi karty zabrudnennia atmosfernoho povitria Lvivshchyny [Creating an interactive map of air pollution in Lviv region]. Molodyi vchenyi, no. 2(66), pp. 303-306.

2. Yarema, N.P., Serant, O.V., Kubrak, O.D., \& Terekh, T.M. (2019). Web-kartohrafuvannia smittiezvalyshch Lvivskoi Oblasti [Web-mapping of landfills in Lviv region]. Molodyi vchenyi, no. 11(75), pp. 167-171.

3. Yarema, N.P., Poliukhovych, Yu.M., Kubrak, O.D., \& Serant, O.V. (2018). Stvorennia interaktyvnoi karty smittiezvalyshch Lvivskoi oblasti [Creating an interactive map of landfills in Lviv region]. Proceedings of the Novi tekhnolohii $v$ heodezii, zemlevporiadkuvanni, lisovporiadkuvanni ta pryrodokorystuvanni: Materialy IX Mizhnarodnoi naukovo-praktychnoi konferentsii (Ukraine, Uzhhorod, October 4-6, 2018). Uzhhorod, pp. 119-123.

\section{Список літератури:}

1. Согор А.Р., Ярема Н.П., Бридун А.М., Лех І.П. Створення інтерактивної карти забруднення атмосферного повітря Львівщини. Молодий вчений. 2019. № 2(66). С. 303-306.

2. Ярема Н.П., Серант О.В., Кубрак О.Д., Терех Т.М. Веб-картографрування сміттезвалищ Львівської області. Молодий вчений. 2019. № 11(75). С. 167-171.

3. Ярема Н.П., Полюхович Ю.М., Кубрак О.Д., Серант О.В. Створення інтерактивної карти сміттезвалищ Львівської області. Нові технологї в геодезї̈, зеллевпорядкуванні, лісовпорядкуванні та природокористуванні : матеріали IX Міжнародної науково-практичної конференції (Ужгород, 4-6 жовтня 2018 р.). Ужгород, 2018. C. $119-123$. 